\title{
ЕЯЕКТРОННІ ОСВІТНІ РЕСУРСИ ДЯЯ ПРОФЕСІЙНОЇ ПІДГОТОВКИ МАЙБУТНІХ ПЕРЕКЛАДАЧІВ В ІНФОРМАЦІЙНО-ОСВІТНЬОМУ СЕРЕДОВИЩІ УНІВЕРСИТЕТУ
}

Потреба у висококвалібікованих перекладачах особливо зростае завдяки міжнародному співробітництву. Це актуалізуе потребу в покращенні якості професійної підготовки майбутніх перекладачів. Електронні освітні ресурси є складовою частиною організаційного і методичного забезпечення освітнього проиесу, використовуються для забезпечення освітньої діяльності університету $і$ вважаються одним із головних елементів його інформаційноосвітнього середовища. До переліку електронних освітніх ресурсів університету, що підлягають процедурі сертибікації як «Навчально-методична розробка університету», відносять: електронний навчально-методичний комплекс; електронний підручник, посібник; дистанційний курс дисципліни. Електронні освітні ресурси відповідають певним вимогам. Основні види електронних освітніх ресурсів наведені у положенні. Подано структуру електронного навчально-методичного комплексу дисиипліни. Електронний навчальний курс має відповідну структуру, схожу зі структурою робочої програми з дисцииліни.

Сучасна філологічна освіта в цілому $і$ перекладацька, зокрема, переживає період активного оновлення електронних навчальних засобів. Електронні підручники та посібники, загалом, мають низку позитивних особливостей, порівняно з такили, щз створені на паперових носіях інформації. Розглянуто критерії визначення якості програмного засобу за кількома напрямами. В умовах розвитку інформаційного суспільства інформатизація освіти неможлива без модернізації змісту навчальних дисцииплін, навчальних і педагогічних практик, навчально-дослідницької та науково-дослідної діяльності студентів у професійній галузі. 3 розвитком соціальних інтернет-мереж студенти і викладачі отримують нові форми $i$ засоби для зберігання й поширення інформації, що полегшуе керування навчальною інформацією і процесом засвоєння знань.

Ключові слова: електронні освітні ресурси, професійна підготовка майбутніх перекладачів, інформаційно-освітне середовище університету.

Постановка проблеми. Розширення міжнародних політичних, економічних і культурних відносин ставлять нові вимоги до рівня підготовки майбутніх перекладачів. Потреба у висококваліфікованих перекладачах особливо зростає завдяки міжнародному співробітництву. Це актуалізуе потребу в покращенні якості професійної підготовки майбутніх перекладачів. Зростає використання сучасних засобів інформаційнокомунікаційних технологій, наявних в інформаційно-освітньому середовищі університетів. У сучасних умовах мережа Інтернет перестає бути засобом, що дозволяє дише одержати доступ до віддаленого ресурсу. Вона сама стає ресурсом, який полегшує вирішення педагогічних завдань: здійснення навчальної діяльності та знаходження навчальних матеріалів.

Аналіз досліджень. Про актуальність вирішення проблеми покращення якості професійної підготовки майбутніх перекладачів в інформаційно-освітньому середовищі університету свідчать численні публікації науковців. Особистісні якості майбутніх перекладачів та їхній вплив на професійну діяльність досліджували Н. Абабілова, Є. Бесєдіна, М. Головань, О. Нестєрова, О. Павдик, Ж. Таланова. Питання створення електронних посібників та підручників розкривається у працях О. Андрєєва, С. Сисоєвої, М. Жалдака та В. Лапінського, Є. Полат.

*C, Долинський Є. В.

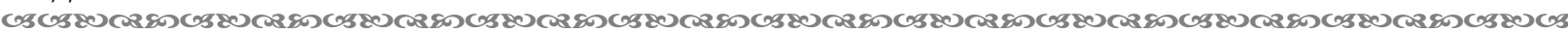


Мета статті - проаналізувати електронні освітні ресурси для професійної підготовки майбутніх перекладачів в інформаційно-освітньому середовищі університету

Виклад основного матеріалу. Ефективність та успішність професійно-практичної підготовки майбутніх перекладачів в інформаційно-освітньому середовищі університету значною мірою залежить від змісту і структури електронних освітніх ресурсів.

Електронні освітні ресурси - це навчальні, наукові, інформаційні, довідкові матеріали та засоби, розроблені в електронній формі та представлені на носіях будьякого типу або розміщені у комп'ютерних мережах, які відтворюються за допомогою електронних цифрових технічних засобів і необхідні для ефективної організації освітнього процесу. Електронні освітні ресурси е складовою частиною організаційного і методичного забезпечення освітнього процессу в університеті і вважаються одним із головних елементів його інформаційно-освітнього середовища.

При використанні електронних освітніх технологій навчальні матеріали та методи обираються за критерієм їхньої ефективності, тобто за найбільшим обсягом знань, засвоюваних за одиницю часу. У положенні [11] розроблена класифікація електронних освітніх ресурсів.

До переліку електронних освітніх ресурсів університету, що підлягають процедурі сертифікації як «Навчально-методична розробка університету», відносять: електронний навчально-методичний комплекс; електронний підручник, посібник; дистанційний курс дисципліни.

Зрозуміло, що для впровадження електронних освітніх ресурсів у процес навчання, вони повинні відповідати певним вимогам. Розглянемо положення про електронні освітні ресурси [там само]. У цьому положенні визначається поняття «електронні освітні ресурси», їх види, порядок розроблення та впровадження.

Метою створення електронних освітніх ресурсів є модернізація освіти, змістове наповнення освітнього простору, забезпечення рівного доступу учасників освітнього процесу до якісних навчальних і методичних матеріалів, незалежно від місця їх проживання та форми навчання, створених на основі інформаційно-комунікаційних технологій [там само].

Основні види електронних освітніх ресурсів наведені у положенні [11]: навчальнометодичні (навчальні плани, робочі програми навчальних дисциплін, розроблені відповідно до навчадьних планів); методичні (методичні вказівки, методичні посібники, методичні рекомендації для вивчення окремого курсу та рекомендації до виконання проєктних робіт, тематичні плани); навчальні (електронні підручники і навчальні посібники); допоміжні (збірники документів і матеріалів, довідники, покажчики наукової та навчальної дітератури, наукові публікації педагогів, матеріали конференцій, електронні довідники, словники, енциклопедії); контродюючі (програми тестів, банки контродьних питань і завдань 3 навчадьних дисциплін та інші електронні освітні ресурси, що забезпечують контроль якості знань) [11].

Арсенал дидактичних можливостей електронних засобів навчального призначення містить такі переваги: різноманітні форми подання інформації та типів навчальних завдань; забезпечення миттєвого зворотного зв' язку; широкі мождивості інтерактивності освітнього процесу; індивідуалізація та диференціація процесу навчання, використання основних і допоміжних навчальних впливів.

Також важливими для нашого дослідження $е$ запропоновані у наукових джерелах [11] загальні вимоги до електронних освітніх ресурсів та інструментальні засоби для їх розроблення: «відповідність змісту програми навчальної дисципліни; наявність відповідних методичних рекомендацій щодо використання електронних освітніх ресурсів; дотримання чинних санітарних норм та ергономічних, програмнотехнічних вимог; дотримання законодавства України із захисту авторських прав» [10, с. 5-6]; необов'язковість дублювання у паперовому варіанті (крім друкованого 
аналога електронного видання); мождивість використання довільних діцензованих або відкритих інструментальних програмно-технічних та апаратних засобів [10, с. 6].

Результативність професійної підготовки майбутніх фахівців, у нашому випадку перекладачів, завдяки розробленому інформаційно-освітньому середовищу багато в чому залежить не тільки від того, які і скільки ІКТ-засобів застосовуються в інформаційно-освітньому середовищі для підтримання навчальної, наукової та професійної діяльності; якої якості ці засоби та технологї; наскільки досконало ними вододіють студенти і викладачі; наскільки активно і педагогічно виважено вони застосовуються. Ці чинники, безумовно, є важдивими для забезпечення високої ефективності процесу професійно-практичної підготовки майбутніх перекладачів в інформаційно-освітньому середовищі.

Результативність роботи в інформаційно-освітньому середовищі залежить також від його побудови, інформаційного та процесуального забезпечення всіх видів діяльності, що можуть відбуватися в ньому, виконуваних функцій, доступності для учасників освітнього процесу [1].

Структура електронного навчально-методичного компдексу дисципліни містить: вихідні дані про навчальну дисципліну та іiі автора(ів), їх фото, рекомендації студенту; робоча програма (опис дисципліни) та рекомендована траєкторія вивчення навчальної дисципліни; електронний навчальний посібник, підручники, задачники; матеріади лекцій (тем); практикум або практичний посібник 3 дисципліни; лабораторний практикум або віртуальні лабораторні роботи; методичні вказівки до практичних (семінарських), лабораторних занять; методичні вказівки до виконання курсових проєктів (робіт); методичні вказівки до виконання контродьних робіт студентами заочної (дистанційної) форми навчання; методичні рекомендації щодо самостійного вивчення дисципліни або іiі частини; завдання для самостійної роботи студентів; тренувальні вправи для самоконтролю знань студента; перелік контрольних заходів та критерії оцінювання результатів навчання для різних видів контродю: вхідного, поточного, семестрового, підсумкової атестації; додаткові інформаційні матеріали: довідкова література; періодичні (галузеві) видання; наукова література; хрестоматії; посилання на бази даних; довідкові системи, електронні словники та мережні ресурси тощо.

Електронний навчальний курс має відповідну структуру, схожу зі структурою робочої програми 3 дисципліни із зазначенням назви дисципліни та ії призначення; відомостей про автора (авторів); робочої програми навчальної дисципліни; рекомендацій студенту щодо вивчення дисципліни; результатів оцінювання навчання; словника; переліку літератури; переліку питань для підсумкового контролю; завдань для контродьних (курсових) робіт з методичними вказівками щодо їх виконання; завдань для лабораторних (практичних, семінарських) занять 3 методичними рекомендаціями щодо їх виконання; навчального матеріалу дисципліни; тестових завдань для поточного та семестрового контролю.

У монографії М. Жалдака, М. Шишкіна, В. Лапінського, К. Скрипки зазначається, що: «існуе значна кількість різних програмних продуктів, які можуть використовуватися у навчанні та подальшій науково-дослідницькій роботі. Виникає потреба визначити й обгрунтувати критерії» [4, с. 53], за якими можна обрати засоби IKT, що будуть використовуватися у професійній підготовці майбутніх перекладачів, а саме:

1. «Методична доцільність. Не всі потужні інструментальні та моделюючі програмні засоби можуть бути методично доцільними при навчальному використанні. Тому необхідно виважено підходити до вибору програмного засобу, враховуючи кдас задач, які можна розв'язувати за його допомогою» [там само, с. 54].

2. «Інтуїтивно-зрозумілий інтерфейс. Вивчення нового програмного засобу завжди викликає певні труднощі у недосвідченого користувача, тому спеціалізований 
програмний засіб має бути зрозумілим не тільки вузькому колу спеціалістів, а й початківцю» [там само].

3. «Україномовний інтерфейс. Більшість програмних засобів спеціального призначення мають англо- або російськомовний інтерфейс, що створює перешкоди для його використання у закладі вищої освіти. Однією з таких є складність овододіння україномовною термінологією» [4, с. 54].

4. «Апаратна сумісність. Програмний продукт повинен злагоджено працювати на наявному парку комп'ютерів, що встановлені у різних закладах освіти» [там само].

5. «Програмна сумісність. Програмний засіб має бути налаштований на роботу під керуванням будь-яких операційних систем, що надасть мождивість його використання незалежно від версії та виробника операційної системи компютера. Також програмний продукт не повинен «конфліктувати» 3 уже встановленим програмним забезпеченням» [там само].

6. «Діцензійна чистота. Користувач програмного продукту повинен мати діцензію на його використання. Якщо програма використовуеться у навчальних цілях, то має бути безкоштовною, у комерційній діяльності - повинна сплачуватись певна кількість коштів. Проте не всі розробники поділяють таку точку зору» [там само].

За тлумаченням М. Жалдака, М. Шишкіна, В. Лапінського, К. Скрипки, вітчизняні програмні засоби здебільшого розраховані на особливості нашої освіти, що «передбачає можливість зворотного зв' язку з розробниками для модернізації програмного засобу та, водночас, уникнення непорозумінь 3 питань авторського права та міжнародного законодавства. Широкий спектр розв'язуваних завдань створює підстави для залучення значної кількості користувачів, які будуть використовувати певний програмний продукт у навчальній та науково-дослідній діяльності» [там само].

Сучасна філологічна освіта в цілому і перекладацька, зокрема, переживає період активного оновлення електронних навчальних засобів. Для того, щоб процес іншомовного навчання став більш цікавим, ефективним, яскравим i творчим, провідними викладачами вітчизняних та зарубіжних університетів розробляються численні навчальні засоби: електронні підручники, посібники, довідково-інформаційні ресурси, віртуальні екскурсії, лабораторії тощо. Серед них Г. Мірам, О. Гон, В. Морозов, М. Нощенко, П. Мовчан, В. Гулик («Практикум з усного перекладу: Мультимедійний формат: навч. посіб. 3 англ. мови для студентів закладів вищої освіти») [12]; О. Гон, В. Гулик, Г. Мірам, В. Морозов, М. Голованчук («Практикум 3 усного перекдаду: Мультимедійний формат. Англо-американський політичний дискурс»); С. Максімов («Усний двосторонній переклад (англійська та українська мови») [8]; С. Максімов («Теорія та практика усного двостороннього перекладу для студентів факультету перекладачів та факультету заочного та вечірнього навчання»); 1 . Черноватий («Методика викладання перекладу у вищій школі»); $\lambda$. Черноватий, В. Карабан («Переклад англійської наукової та технічної дітератури») та ін., що відповідають нормам ДСТУ 3019-95.

Водночас із створенням електронних освітніх ресурсів відбувається виокремлення та осмислення вимог щодо їх розроблення та функціонування. Слід зазначити, що у сучасній педагогіці обговорюються загальні вимоги до електронних, зокрема, мудьтимедійних, навчальних засобів, майже без урахування специфіки предмета навчання. Науковці, які розробляють теорію використання електронних засобів навчального призначення (В. Биков [1], М. Жалдак [4], В. Лапінський [7], М. Шишкіна, I. Роберт та ін.), аналізують загадьнодидактичні, методичні, психологічні вимоги до електронних освітніх ресурсів.

На думку С. Сисоєвої, «незважаючи на різні визначення сутності і структури електронного підручника, найпоширенішим є погляд на нього «як на програмнометодичний комплекс, що дозволяе самостійно вивчити навчальний курс або його 
розділи і який об'єднуе за змістом: підручник, довідник, задачник і иабораторний практикум» [4, с. 46].

У праці М. Жалдака [4] знаходимо визначення, що електронний підручник це «комп'ютерна навчальна система, яка включає дидактичні, методичні та інформаційно-довідкові матеріали 3 навчальної дисципліни, а також програмне забезпечення, що дозволяє комплексно використовувати їх для самостійного отримання та контролю результатів освітніх досягнень» [4, с. 46-47].

Важливо зазначити, що «електронні підручники та посібники, загалом, мають низку позитивних особливостей, порівняно з такими, що створені на паперових носіях інформації. Йдеться про компактність зберігання навчальних відомостей на магнітному носії чи в мережі Інтернет, використання навчадьно-методичних гіпертекстових даних довідкового характеру нелінійної та багаторівневої структури, зручну систему навігації електронним підручником, широкі можливості оформлення навчального матеріалу, 3 використанням графічних, аудіовізуальних та анімаційних об'єктів (мультимедійних засобів)» [там само, с. 47].

На думку С. Сисоєвої, «електронний посібник не є альтернативою традиційним освітнім засобам, він може застосовуватись у педагогічно доцільному з ними поєднанні, з використанням переваг, які дає комп'ютер» [там само, с. 48].

До того ж, «едектронний посібник - це інтерактивний програмний засіб, розрахований на самостійну позааудиторну навчально-пізнавальну діяльність студентів і призначений для формування готовності до професійної діяльності. «Він передбачає реалізацію процесу самонавчання студентів із дисциплін, що вивчаються, та виконання професійно спрямованих навчальних тестових завдань репродуктивного, логічного і продуктивного рівнів складності, та організацію керування навчально-пізнавальною діяльністю, залежно від цільових намірів суб' єктів навчання» [там само, с. 48].

Він «має доповнювати навчальний посібник на паперових носіях 3 цієї ж дисципліни щодо функцій та основних дидактичних завдань, у процесі професійної підготовки. Відбір змісту електронного посібника має здійснюватися з урахуванням модульної робочої програми та чинних вимог до формування готовності майбутніх фахівців до професійної діяльності» [там само, с. 48].

На думку М. Жалдака, В. Лапінського, М. Шута: «загальні вимоги до якості електронного посібника як програмного засобу, сформульовані у формі номенклатури показників якості першого i другого рівнів ДСТУ 2850-94 та показників якості за державним стандартом 28195-84, яким повинні відповідати будь-які товарні (призначені для використання не лише самим розробником) програмні засоби, є необхідними, але недостатніми для визначення придатності використання програмного засобу у процесі навчання» [там само, с. 49].

Дослідження показало, що «науковці згрупували критерії визначення якості програмного засобу за кількома напрямами: загальні та спеціальні вимоги, суть яких полягає в мірі їх відповідності загальним дидактичним вимогам і вимогам методики навчання певної дисципліни, враховуючи форму навчання та тип заняття, в умовах якого використовуватиметься цей засіб навчання; доцільність використання програмного засобу на певному етапі навчання, що визначається вищою, ніж при застосуванні традиційних засобів, ефективністю навчання; визначення форми та провідного виду навчальної діяльності під час роботи 3 певним програмним засобом, типів навчальних завдань та місця в освітньому процесі, де він застосовуватиметься; ергономічні вимоги, що визначають параметри програмного засобу, які впливають на його ефективність як засобу навчання і на його безпеку для фізичного та психічного здоров'я тих, хто навчається; технічні вимоги, що визначають рівень технічної досконадості і складності програмного засобу, його структури та стійкості до помилкових дій користувача» [там само, с. 49-51]. 
В «Енциклопедії освіти» за редакцією В. Кременя зазначається, що критерії це сукупність ознак, на основі яких складається оцінка умов, процесу і результатів навчальної діяльності, що відповідають поставленим цілям [2].

Загалом в «освітній діяльності студентів виокремлюють такі напрями оцінювання якості навчання, що співвідносяться з певними факторами: мотивація (уміння визначати навчальні потреби, виокремлювати навчальні пріоритети, пов'язувати навчальні дії з власними інтересами); цілепокладання (здатність визначати знання та вміння, які необхідні для розв'язання проблеми); навчальні дії (рівень сформованості загальнонавчальних умінь, можливість творчого використання нових знань); контроль і самоконтроль (спроможність зіставлення нових знань 3 еталоном, стандартом, алгоритмом дій тощо); корекція і самокорекція (уміння проводити поточне коригування відхилень, спроможність самостійного спрямування своїх дій на результат); оцінювання і самооцінювання (здатність об'єктивно визначати свій наявний рівень освітніх досягнень, ступінь підвищення студентом продуктивності навчальної діяльності)» [5].

У роботах У. Когута [6], Д. Покришеня [9] здійснено аналіз програмних засобів, які доцільно використовувати в освітньому процесі, а саме: «все програмне забезпечення повинне відповідати загальновизначеним дидактичним вимогам; програмний продукт не повинен перевантажуватися додатковими опціями та характеристиками, які можуть відволікти або налякати недосвідченого користувача; мождивість активації чи відключення певних опцій; комп'ютер повинен бути робочим місцем, де розміщені усі необхідні інструменти для навчально-дослідної діяльності, а не дише подавати певні повідомлення; програма має реалізовуватися 3 використанням рідної мови для користувача і не переобтяжуватися технічними термінами; у зовнішньому вигдяді головного вікна повинні бути стандартні елементи: меню, контекстне меню, робоча багатовіконна область, передбачене виконання дій за допомогою клавіатури та мишки; необхідна структурована та розроблена рідною мовою система підтримки користувача; стійкість до помилок у діях користувача щодо внесення даних; в обраному програмному засобі повинна бути навчадьно-методична література 3 доступно викладеним теоретичним матеріалом, детальним розгдядом конкретних прикладів використання різних можливостей програми, достатньою кількістю питань та вправ для самоконтродю» [6, с. 90].

Таким чином, вивчення майбутніми перекладачами у закладі вищої освіти професійно-практичних дисциплін і дисципліни «Інформаційні технології упрофесійній діяльності перекладача» спрямоване на: формування навичок використання освітніх інтернет-ресурсів у майбутній професійній діяльності, ознайомлення 3 можливостями засобів сучасних інформаційних технологій, що використовуються у професійній діяльності перекладачів; навчання працювати 3 відповідним програмним забезпеченням; формування практичних навичок і вмінь на основі поєднання теоретичних знань i практичних перекладів засобами інформаційно-комунікаційних технологій.

В умовах розвитку інформаційного суспільства, інформатизація освіти неможлива без модернізації змісту навчальних дисциплін, навчальних і педагогічних практик, навчально-дослідницької та науково-дослідної діяльності студентів у професійній галузі.

Ефективність навчальної діяльності і результат успішності професійно-практичної підготовки майбутніх перекладачів в інформаційно-освітньому середовищі університету значною мірою залежить від змісту і структури електронних освітніх ресурсів. Кожен вид електронних освітніх ресурсів створюеться і планується для розміщення у загальнодоступній формі у конкретній інформаційній системі університетського інформаційного середовища, зокрема в його електронній бібліотеці; в інформаційному середовищі дистанційного навчання; у модульному середовищі для навчання Moodle. 
3 розвитком соціальних інтернет-мереж студенти і викладачі отримують нові форми і засоби для зберігання й поширення інформації, що полегшує керування навчальною інформацією і процесом засвоєння знань. Соціальні мережі допомагають вирішувати різні ситуації, сприяють творчому підходу до професійної підготовки. На сьогодні соціальні мережі стали важливим елементом інформаційного простору суспільства, вплив яких зростає прямо пропорційно з рівнем інтернатизації населення. На основі аналізу літературних джерел визначено поняття «інтернет-блог» як середовища професійного розвитку викладачів і студентів спеціальності переклад. Охарактеризовано, що блог або сайт - це нова форма комунікації між студентами і викладачем, яка об'єднуе різних авторів, дозволяючи їм підтримувати інтерактивні відносини у різних мультимедійних форматах. Наведено приклади тематичних перекладацьких блогів, що створені студентами-перекладачами Хмельницького національного університету та можуть використовуватись у навчальній діяльності.

Висновки. Задля здійснення професійної підготовки майбутніх перекладачів урізноманітнено та доповнено навчально-методичне забезпечення, зокрема навчальні програми та навчально-методичні матеріади 3 дисциплін професійної та практичної підготовки, до яких увійшли: навчальні посібники, методичні вказівки, контродьновимірювальні матеріали (контрольні завдання, комплекти тестових завдань для комп'ютерної перевірки сформованості знань студентів); електронні навчальнометодичні комплекси, розроблені і розміщені в навчальному середовищі Moodle 3 дисциплін професійної та практичної підготовки, які містять: методичні матеріали (навчальна і робоча навчальна програми), навчальні матеріали (конспекти лекцій, мультимедійні презентації, практичні заняття, завдання для самостійної роботи, індивідуальні навчально-дослідні завдання), матеріали для контролю знань (тестові завдання, завдання для модульного контродю, запитання до іспиту), додаткові матеріали (електронні словники, довідники, підручники з перекладу, іноземної мови, навчально-методичні розробки, навчальні посібники, відеотека). Важдиве значення мають електронні освітні ресурси для професійної підготовки майбутніх перекладачів в інформаційно-освітньому середовищі університету, яке потребуе подальшого наукового дослідження.

\section{Список використаних джерел:}

1. Биков В. Ю. Мобільний простір і мобільно орієнтоване середовище інтернет-користувача: особливості модельного подання та освітнього застосування. Інформаційні технологї в освіті. Херсон, 2013. Вип. 17. С. 9-37. URL: http://nbuv.gov.ua/UIRN/itvo 2013173

2. Енциклопедія освіти / голов. ред. В. Г. Кремень. Київ : Юрінком Інтер, 2008. 1040 с.

3. Жалдак М. І., Лапінський В. В., Шут М. І. Комп'ютерно-орієнтовані засоби навчання математики, фізики, інформатики. Інформатика. Київ : Шкільний світ. 2006. № 3-4. 96 с.

4. Жалдак М. І., Шишкіна М. П., Лапінський В. В., Скрипка К. І. Оцінювання якості програмних засобів навчального призначення для загальноосвітніх навчальних закладів : монографія / за наук. ред. проф. М. І. Жалдака. Київ : Педагогічна думка, 2012. 132 с. URL: http://lib.iitta.gov.ua/619/4/Ocin Jakost PZ.pdf

5. Коваль А. В. Система професійної підготовки майбутніх учителів початкової школи до застосування загальнонавчальних технологій : дис. ... д-ра пед. наук: 13.00.04. Бердянськ, 2010. 532 c.

6. Когут У.П. Класифікація та критерії вибору програмних засобів для фундаменталізації підготовки бакалаврів інформатики з інформатичних дисциплін. Інформаційні технології в освіті. 2012. Вип. 11. С. 88-97. URL: http://nbuv.gov.ua/UJRN/itvo 20121115

7. Лапінський В. В. Навчальне середовище нового покоління та його скдадові. Науковий часопис НПУ ім. М. П. Арагоманова. Серія 2 : Коми'ютерно-орієнтовані системи навчання : зб. наук. пр. Київ : НПУ ім. М. П. Драгоманова, 2008. № 6 (13). С. 26-32.

8. Максімов С. Є. Усний двосторонній переклад (ангдійська та українська мови). Теорія та практика усного двостороннього перекладу для студентів факультету перекладачів 
та факультету заочного та вечірнього навчання (+2 компакт-диски) : навч. посіб. 2-ге вид., випр. та допов. Київ : Ленвіт, 2007. 416 с.

9. Покришень Д. А. Програмно-педагогічне забезпечення міжпредметних зв'язків інформатики 3 математикою і фізикою у навчанні майбутніх інженерів: дис. ... канд. пед. наук : 13.00.02. Київ, 2010. 239 с.

10. Подоження про електронний навчально-методичний комплекс забезпечення навчальної дисципліни. Державний університет телекомунікацій. Київ, 2015. URL: http://www.dut.edu.ua/uploads/p 1579 60337886.pdf

11. Про затвердження Положення про електронні освітні ресурси: наказ МОН України від 01.10.2012 p. № 1060. URL: http: zakon2.rada.gov.ua/laws/ show/z1695-12

12. Miram G. Translation: A course of lectures on translation theory and practice for institutes and departments of international relations. Київ : Ніка-Центр, 2002. 238 c.

\section{References:}

1. Bykov, V. Yu. (2013). Mobilnyi prostir i mobilno oriientovane seredovyshche internetkorystuvacha: osoblyvosti modelnoho podannia ta osvitnoho zastosuvannia [Mobile space and mobile-oriented environment of the Internet user: features of model representation and educational application]. Informatsiini tekhnolohii $v$ osviti, 17, 9-37. Retrieved from http://nbuv.gov.ua/UIRN/itvo 2013173 [in Ukrainian].

2. Kremen, V. H. (Ed.). (2008). Entsyklopediia osvity [Encyclopedia of Education]. Kyiv: Yurinkom Inter [in Ukrainian].

3. Zhaldak, M. I., Lapinskyi, V. V., \& Shut, M. I. (2006). Kompiuterno-oriientovani zasoby navchannia matematyky, fizyky, informatyky [Computer-based teaching aids for Mathematics, Physics, Computer Science]. Informatyka, 3-4, 96 [in Ukrainian].

4. Zhaldak, M. I., Shyshkina, M. P., Lapinskyi, V. V., \& Skrypka, K. I. (Ed.). (2012). Otsiniuvannia yakosti prohramnykh zasobiv navchalnoho pryznachennia dlia zahalnoosvitnikh navchalnykh zakladiv [Quality assessment of educational software for secondary schools]. Kyiv: Pedahohichna dumka. Retrieved from http://lib.iitta.gov.ua/619/4/Ocin Jakost PZ.pdf [in Ukrainian].

5. Koval, L. V. (2010). Systema profesiinoi pidhotovky maibutnikh uchyteliv pochatkovoi shkoly do zastosuvannia zahalnonavchalnykh tekhnolohii [The system of professional training of future primary school teachers for the use of general educational technologies]. (Doctor's thesis). Berdiansk [in Ukrainian].

6. Kohut, U. P. (2012). Klasyfikatsiia ta kryterii vyboru prohramnykh zasobiv dlia fundamentalizatsii pidhotovky bakalavriv informatyky $\mathrm{z}$ informatychnykh dystsyplin [Classification and selection criteria of software for fundamentalization of bachelors of Computer Science in computer science disciplines]. Informatsiini tekhnolohii $v$ osviti, 11, 88-97. Retrieved from http://nbuv.gov.ua/UJRN/itvo_2012_11_15 [in Ukrainian].

7. Lapinskyi, V. V. (2008). Navchalne seredovyshche novoho pokolinnia ta yoho skladovi [The learning environment of the new generation and its components]. Naukovyi chasopys NPU im. M. P. Drahomanova. Seriia 2: Kompiuterno-oriientovani systemy navchannia, 6(13), 26-32 [in Ukrainian].

8. Maksimov, S. Ye. (2007). Usnyi dvostoronnii pereklad (anhliiska ta ukrainska movy). Teoriia ta praktyka usnoho dvostoronnoho perekladu dlia studentiv fakultetu perekladachiv ta fakultetu zaochnoho ta vechirnoho navchannia (+2 kompakt-dysky) [Bilateral interpretation (English and Ukrainian). Theory and practice of two-way interpretation for students of the Faculty of Translators and the Faculty of Distance and Evening Studies (+2 CDs)]. Kyiv: Lenvit [in Ukrainian].

9. Pokryshen, D. A. (2010). Prohramno-pedahohichne zabezpechennia mizhpredmetnykh zviazkiv informatyky $z$ matematykoiu $i$ fizykoiu u navchanni maibutnikh inzheneriv [Program-pedagogical support of interdisciplinary connections of Informatics with Mathematics and Physics in training of future engineers]. (Candidate's thesis). Kyiv [in Ukrainian].

10. Polozhennia pro elektronnyi navchalno-metodychnyi kompleks zabezpechennia navchalnoi dystsypliny [Regulations on the electronic educational and methodical complex of providing academic discipline]. (2015). Derzhavnyi universytet telekomunikatsii. Kyiv. Retrieved from http://www.dut.edu.ua/uploads/p 1579 60337886.pdf [in Ukrainian].

11. Order of the Ministry of Education and Science of Ukraine dated October 01, 2012 No. 1060. On approval of the Regulation on electronic educational resources. Retrieved from http://zakon2.rada.gov.ua/laws/ show/z1695-12 [in Ukrainian].

os 
12. Miram, G. (2002). Translation: a course of lectures on translation theory and practice for institutes and departments of international relations. Kyiv: Nika-Tsentr [in English].

\section{ELECTRONIC EDUCATIONAL RESOURCES FOR PROFESSIONAL TRAINING OF FUTURE TRANSLATORS IN THE INFORMATION AND EDUCATIONAL ENVIRONMENT OF THE UNIVERSITY}

The need for highly qualified translators is especially growing due to international cooperation. This highlights the need to improve the quality of training of future translators. Electronic educational resources are an integral part of the organizational and methodological support of the educational process, used to support the educational activities of the university and is considered one of the main elements of its information and educational environment. The list of electronic educational resources of the university, which are subject to the certification procedure as "Educational and methodical development of the university", includes: electronic educational and methodical complex; electronic textbook, manual; distance course of the discipline. Electronic educational resources meet certain requirements. The main types of electronic educational resources are given in the provision. The structure of the electronic educational and methodical complex of the discipline is given. The e-learning course has an appropriate structure similar to the structure of the work program in the discipline.

Modern philological education in general and translation, in particular, is experiencing a period of active renewal of e-learning tools. Electronic textbooks and manuals, in general, have a number of positive features, compared to those created on paper. The criteria for determining the quality of the software in several areas are considered. In the development of the information society, the informatization of education is impossible without the modernization of the content of academic disciplines, educational and pedagogical practices, teaching and research activities of students in the professional field. With the development of social Internet networks, students and teachers receive new forms and tools for storing and disseminating information, which facilitates the management of educational information and the process of learning.

Key words: electronic educational resources, professional training of future translators, information and educational environment of the university.

Дата надходження статті: 22.04.2021 p. Рецензент: доктор педагогічних наук, професор Гахус О. М.

У, ДК 378:37.091

DOI https://doi.org/10.37915/pa.vi49.259

Задорожна I. П. , orcid.org/0000-0003-1599-1372

\section{СУЧАСНІ ПІДХОДИ ДО ФОРМУВАННЯ ІНШОМОВНОї АУ ДИТИВНОЇ КОМПЕТЕНТНОСТІ}

у статті проаналізовано сучасні підходи до формування іншомовної аудитивної компетентності учнів/студентів та визначено можливості оптимізації процесу навчання. Зроблено висновок про доцільність диференційованого розвитку психічних процесів (сприйняття, мислення, пам'ять, увага), психологічних механізмів (мовленнєвий слух, внутрішне промовляння, ймовірнісне прогнозування, осмислення, оперативна пах'ять, механізм розрізнення та ідентифікації), а також механізмів смислової обробки інформації

*C) Задорожна I. П.

بs 